\title{
TRUMAN CAPOTE'S OTHER VOICES, OTHER ROOMS AND CENSORSHIP IN COMMUNIST ROMANIA
}

\author{
GE OR G E V O L C E A N O V \\ "Spiru Haret” University, Bucharest
}

\begin{abstract}
The paper presents the censored fragments of Mircea Ivănescu's Romanian translation of Truman Capote's Other Voices, Other Rooms, published by Univers Publishing House in 1978 , as well as the translator's (or the censor's?) contribution to the "edulcoration" of certain details that did not comply with the Communist ethics of the late 1970s; it also discusses the reason why the Romanian version underwent a purging process at the time. Another issue tackled in the paper is the appraisal of Ivănescu's merits and demerits as a renowned translator, in general, and as the translator of Capote's novel, in particular.
\end{abstract}

Keywords: gay literature, Communist ethics, censorship, Truman Capote, faithfulness to the original, redundancy, Mircea Ivănescu

\section{Gay Literature and Communist Censorship}

In December 2014 Polirom, one of the leading Romanian publishing houses, commissioned me to re-translate Truman Capote's Other Voices, Other Rooms. It was for the second time in three years that the same publishers were asking me to re-translate a work of fiction previously rendered into Romanian by the late Mircea Ivănescu, one of the most renowned Romanian translators of the past four decades, whose list of translated authors includes the names of James Joyce, William Faulkner, Robert Musil, T. S. Eliot and F. Scott Fitzgerald. Previously, I had been assigned to re-translate Fitzgerald's The Great Gatsby and this had turned out to be a profitable venture for the publishers, in so far as for my new version I received a translation award in November 2014.

The whole discussion in this paper is based on first-hand observations made in the process of re-translating Other Voices, Other Rooms rather than on extensive bibliographical reading. While working at my translation, I did not hesitate to revisit Ivănescu's earlier version, because I do share Czesław Miłosz's view that, in the case of re-translations, it is a must for the new translator to consult older translations (Romanowska 18). Moreover, back in 
1978, as an undergraduate in English studies, I had found Ivănescu's translation a great artistic feat, a "mirror" of all great translations (to use Shakespeare's metaphor for a positive example of any kind). It was while comparing the new translation and the earlier one that I noticed the absence of a number of paragraphs, sentences, phrases and words from the latter, as well as the edulcoration of some other passages; Ivănescu's version reinforced my conviction (already forged while re-translating The Great Gatsby) that the great poet Mircea Ivănescu was not all that he was cracked up to be as a literary translator.

The new Romanian version came out in print in late March, 2015, in the best-selling collection TOP $10+$, and the cover of the book contains a blurb added to the author's name and title of the novel, which reads: "The first uncensored edition, in a new translation by George Volceanov." The answer to the question "Why was Capote's novel censored in Communist Romania?" is quite simple: the sexual behaviour and orientation of some of the characters in the novel did not meet the demands of Communist ethics. It was unacceptable, at the time, to approach an issue like homosexuality (considered a deviation from norms) as well as other "perverse" inclinations such as transvestism. Several generations of Romanian readers have read Other Voices, Other Rooms as a typical Bildungsroman, a Gothic and romantic tale dedicated to adolescence. Today's readers are invited to regard it as a piece of gay literature. Anthony Slide notes that more than fifty years after its publication, Other Voices, Other Rooms is one of only four familiar gay novels of the first half of the twentieth century. The other three novels are Djuna Barnes' Nightwood, Carson McCullers' Reflections in a Golden Eye, and Gore Vidal's The City and the Pillar.

A brief look at the fate of the four aforementioned novels in communist Romania substantiates the validity of this hypothesis. Gore Vidal's The City and the Pillar (1948) was first published in Romanian after the fall of Communism (Univers Publishing House, 1996); Carson McCullers' earlier novel Reflections in a Golden Eye (1941) was first translated and issued in Romania(n) only as late as 2003 (Humanitas Publishing House), while Djuna Barnes' pioneering Nightwood (1936), which tackles the issue of lesbianism, is currently being translated and is due to be issued this year by Humanitas Fiction Publishing House.

So, Capote's novel is the fourth on a list of illustriously uncanny novels dealing with the once taboo subject of homosexuality; curiously, women writers preceded male authors in the field. It was Djuna Barnes who first dared break this taboo, soon followed by Carson McCullers, who, incidentally, was the Southern authoress that actively helped the younger Truman Capote make his debut. Unlike Vidal's overtly gay novel, Other Voices,Other Rooms is subtler, weaving a "Southern Gothic" story about a thirteen-year old orphan boy's quest 
for his father and, ultimately, for his own identity. A series of either narrated, experienced or witnessed erotic scenes (narrated by Cousin Randolph, experienced in a children's game by Idabel and Joel, or witnessed via voyeurism by Joel alone or Joel and Idabel) subtly point, at the end of the novel, to the protagonist's discreet and discrete sexual orientation.

\section{Deviant Conduct and Excised Passages}

Being more than just a gay novel, Other Voices, Other Rooms could easily be reinvented by the vigilant Romanian censorship, in blurbs printed on the back cover of the 1978 edition, as a text of stylistic perfection (Norman Mailer) dealing with a "world haunted by the melancholy beauty of decline and the poetry of the grotesque" (Heinrich Böll).

During the years spent in New Orleans, when his mother was still alive, little Joel was playing the part of a private investigator, peeping through the window into the houses of his neighbourhood. The child is astonished to see one night what to him appears to be something incredible (hereafter I shall use the acronyms TC for Truman Capote, MI for Mircea Ivănescu, and GV for George Volceanov in the parallel presentation of fragments from the original work and its Romanian versions. The bold italics below mark the censored passages in the original and their restoration in my translation.)

\begin{tabular}{|c|c|c|}
\hline $\begin{array}{l}\text { lackmail was practiced } \\
\text { New Orleans only } \\
\text { fter sunset, inasmuch as } \\
\text { aylight could be fatal } \\
\text { or a player, the idea } \\
\text { eing to approach a } \\
\text { range house and peer } \\
\text { ivisibly through its } \\
\text { indows. On these } \\
\text { angerous evening } \\
\text { atrols, Joel had } \\
\text { itnessed many peculiar } \\
\text { eectacles, like the night } \\
\text { 'd watched a young } \\
\text { irl waltzing stark naked } \\
\text { victrola music; and, } \\
\text { gain, an old lady drop } \\
\text { ead while puffing at a } \\
\text { iryland of candles } \\
\text { urning on a birthday }\end{array}$ & $\begin{array}{l}\text { lecât } \\
\text { elui, } \\
\text { zilei ar fi } \\
\text { ătorului, } \\
\text { în a te } \\
\text { străină } \\
\text { zut, prin } \\
\text { enea } \\
\text { e } \\
\text { l avusese } \\
\text { ectacole } \\
\text { iptea } \\
\text { ă tânără } \\
\text { ind după } \\
\text { nofon; } \\
\text { ină } \\
\text { sse jos și } \\
\text { nusase }\end{array}$ & $\begin{array}{l}\text { În New Orleans, jucau } \\
\text { şantajul doar după apusul } \\
\text { soarelui, căci lumina zilei } \\
\text { i-ar fi putut fi fatală unui } \\
\text { jucător, tot jocul constând } \\
\text { în a te apropia de o } \\
\text { locuinţă străină şi a te uita } \\
\text { pe fereastră fără să fii } \\
\text { văzut de cei dinăuntru. În } \\
\text { timpul acestor } \\
\text { primejdioase patrulări } \\
\text { nocturne, lui Joel îi fusese } \\
\text { dat să vadă multe } \\
\text { spectacole ciudate, ca în } \\
\text { noaptea când o urmărise } \\
\text { pe-o puştoaică valsând } \\
\text { goală puşcă pe muzica } \\
\text { unui patefon; sau pe } \\
\text { bătrâna doamnă care } \\
\text { căzuse moartă pe când }\end{array}$ \\
\hline
\end{tabular}




\begin{tabular}{|l|l|l|}
\hline $\begin{array}{l}\text { cake; and most puzzling } \\
\text { of all, two grown men } \\
\text { standing in an ugly little } \\
\text { room kissing each other. } \\
\text { (TC, 35) }\end{array}$ & $\begin{array}{l}\text { feerie de lumânări pe un } \\
\text { tort de aniversare. (MI, }\end{array}$ & $\begin{array}{l}\text { sufla într-o feerie de } \\
\text { lumânări aprinse pe tortul } \\
\text { ei aniversar; şi, cea mai } \\
\text { bizară chestie dintre } \\
\text { toate, pe doi bărbaţi care } \\
\text { se sărutau, stând în } \\
\text { picioare, într-o cămăruţă } \\
\text { urâtă. }(\mathbf{G V}, 69)\end{array}$ \\
\hline
\end{tabular}

It was the absence of this passage from the earlier translation that first drew my attention to the possibility of censorship at work. And further such instances confirmed my hunch. It was quite obvious that "two grown men... kissing each other" conflicted with the ideology of the Communist age, which strongly encouraged heterosexual intercourse and marriage as a means to implement demographic growth.

In the next both doctored and purged passage, Cousin Randolph, on his way to self-revelation, to the acknowledgment that he had been a latent homosexual for years, comments on the fact that it is men, not women, that should judge masculine personality, and on his own feelings for a man:

\begin{tabular}{|c|c|c|}
\hline $\begin{array}{l}\text {...[Dolores] had no } \\
\text { personal feeling or } \\
\text { respect for men or the } \\
\text { masculine personality... } \\
\text { that personality which, } \\
\text { despite legend, can only } \\
\text { be the most sensitively } \\
\text { appreciated by its own } \\
\text { kind. [...] and suddenly, } \\
\text { with a mild shock, I } \\
\text { realized it was not she } \\
\text { of whom I was jealous, } \\
\text { but him. (TC, 72) }\end{array}$ & $\begin{array}{l}\text {...n-avea nici un fel de } \\
\text { simțăminte sau respect } \\
\text { pentru bărbați sau pentru } \\
\text { personalitatea } \\
\text { masculină... această } \\
\text { personalitate care, în } \\
\text { ciuda legendelor, nu } \\
\text { poate fi apreciată cu } \\
\text { sensibilitate decât de cei } \\
\text { din aceeași categorie. } \\
\text { (MI, 118) }\end{array}$ & $\begin{array}{l}\text {...nu avea nici un fel } \\
\text { sentimente sau de respect } \\
\text { pentru bărbaţi sau pentru } \\
\text { personalitatea } \\
\text { masculină... } \\
\text { personalitate care, în } \\
\text { pofida tuturor } \\
\text { legendelor, poate fi } \\
\text { apreciată cu sensibilitate } \\
\text { doar de către bărbaţi. } \\
{[\ldots . .] \text { si dintr-odată, niţel }} \\
\text { şocat, mi-am dat seama } \\
\text { că nu pe ea eram gelos, } \\
\text { ci pe el. (GV, 149) }\end{array}$ \\
\hline
\end{tabular}

Ivănescu translated Capote's its own kind, which obviously refers to man, obliquely, as category, and thus turned a simple statement into an ambiguity. Moreover, he, the editor, or the censor cautiously left out Randolph's ultimate confession that it was not of Dolores that he was jealous, but of Pepe Alvarez. 
One of the two longest excised passages closely follows Randolph's admission and reads as follows:

\begin{tabular}{|c|c|c|}
\hline $\begin{array}{l}\text { Afterwards, and though } \\
\text { at first I was careful not } \\
\text { to show the quality of my } \\
\text { feelings, Dolores } \\
\text { understood intuitively } \\
\text { what had happened: } \\
\text { "Strange how long it } \\
\text { takes us to discover } \\
\text { ourselves; I've known } \\
\text { since first I saw you," she } \\
\text { said, adding, "I do not } \\
\text { think, though, that he is } \\
\text { one for you; I've known } \\
\text { too many Pepes: love him } \\
\text { if you will, it will come } \\
\text { to nothing." The brain } \\
\text { may take advice, but not } \\
\text { the heart, and love, } \\
\text { having no geography, } \\
\text { knows no boundaries: } \\
\text { weight and sink it deep, } \\
\text { no matter, it will rise and } \\
\text { find the surface: and why } \\
\text { not? Any love is natural } \\
\text { and beautiful that lies } \\
\text { within a person's nature; } \\
\text { only hypocrites would } \\
\text { hold a man responsible } \\
\text { for what he loves, } \\
\text { emotional illiterates and } \\
\text { those of righteous envy, } \\
\text { who, in their agitated } \\
\text { concern, mistake so } \\
\text { frequently the arrow } \\
\text { pointing to heaven for the } \\
\text { one that leads to hell. } \\
\text { It was different, this love } \\
\text { of mine for Pepe, more } \\
\text { intense than anything I }\end{array}$ & (MI, 118) & $\begin{array}{l}\text { După aceea, deși am avut } \\
\text { grijă să nu-mi dau în } \\
\text { vileag sentimentele, } \\
\text { Dolores a priceput, } \\
\text { intuitiv, ce s-a întâmplat. } \\
\text { - E ciudat, cât de mult } \\
\text { timp ne ia să ne } \\
\text { descoperim pe noi înşine; } \\
\text { mi-am dat seama de când } \\
\text { te-am văzut prima oară, } \\
\text { spuse ea și adăugă: } \\
\text { Totuși, nu cred că e omul } \\
\text { potrivit pentru tine; am } \\
\text { cunoscut la viața mea prea } \\
\text { mulți Pepe de-ăștia: dacă } \\
\text { vrei, n-ai decât să-1 } \\
\text { iubești, dar n-o să } \\
\text { se-aleagă nimic din asta. } \\
\text { Mintea o fi ascultând de } \\
\text { sfaturi, însă nu și inima, } \\
\text { iar dragostea, neavând o } \\
\text { geografie a ei, este } \\
\text { nemărginită: agață-i un } \\
\text { lest și scufund-o la mare } \\
\text { adâncime, tot o să se } \\
\text { ridice și o să iasă la } \\
\text { suprafață. Şi de ce nu? } \\
\text { Orice iubire care } \\
\text { sălășluiește în firea unei } \\
\text { persoane e firească și } \\
\text { frumoasă; doar ipocriții } \\
\text { l-ar socoti răspunzător pe } \\
\text { un bărbat pentru obiectul } \\
\text { iubirii sale, analfabeții } \\
\text { într-ale sentimentelor și } \\
\text { invidioșii justițiari, care, } \\
\text { în îngrijorarea lor } \\
\text { zbuciumată, confundă atât } \\
\text { de des săgeata ce indică }\end{array}$ \\
\hline
\end{tabular}




\begin{tabular}{|l|l|}
\hline $\begin{array}{l}\text { felt for Dolores, and } \\
\text { lonelier. }(\mathrm{TC}, 72)\end{array}$ & $\begin{array}{l}\text { drumul spre rai cu cea } \\
\text { care arată calea spre iad. } \\
\text { Iubirea asta mea pentru } \\
\text { Pepe era cu totul altfel, } \\
\text { mult mai intensă decât } \\
\text { orice simțisem pentru } \\
\text { Dolores și mult mai } \\
\text { solitară. }(\mathrm{GV}, 149)\end{array}$ \\
\hline
\end{tabular}

Capote reveals how sensitive a would-be deviant can be; Randolph's confession is also a proof that gay love may be a profound and innocent feeling, not a dirty pastime. The metaphors (geography, pointing signs) confirm the fact that Capote is one of the greatest stylists of American fiction.

Randolph's narrative continues with the account of a night walk during which he meets a boy and nothing really happens with the two of them, except for a fleeting moment of tenderness expressed in the following quotation; Ivănescu's version has two words removed due to their gay connotation:

\begin{tabular}{|l|l|l|}
\hline ...there was a blond & ...un băiat blond cam & ... alături ședea un puști \\
misty boy sitting beside & cețos se așezase alături & blond, cam neguros, care \\
me, and he looked at me, & de mine, și mă privea, și & s-a uitat la mine, iar eu \\
and I at him, and we & eu îl priveam, și nu eram & m-am uitat la el și nu \\
were not strangers: our & străini: mâinile ni se & eram deloc doi \\
hands moved towards & întindeau unul spre altul. & necunoscuți: mâinile ni \\
each other to embrace. & (MI, 119) & s-au întins unul spre \\
(TC, 73) & & celălalt, să ne strângem \\
& & in brațe. $\mathbf{G V , 1 4 9 )}$ \\
\hline
\end{tabular}

Next comes Randolph's account of the Mardi Gras and its ball. Ivănescu's translation preserves the details about the costumes Randolph's friends are going to wear: Ed is a Franciscan monk, Pepe a bandit and Dolores a ballerina... How about Randolph? This is the second largest passage removed from the first Romanian translation:

\begin{tabular}{|c|c|c|}
\hline $\begin{array}{l}\text {...but I cannot think what } \\
\text { to wear and this becomes } \\
\text { a dilemma of } \\
\text { disproportionate } \\
\text { importance. Dolores } \\
\text { appears the night of the } \\
\text { ball with a tremendous }\end{array}$ & $\begin{array}{l}\text {...numai eu nu mă pot } \\
\text { hotărî ce costum să aleg } \\
\text { și asta de vine o dilemă } \\
\text { disproporționată. (MI, } \\
\text { 119) }\end{array}$ & $\begin{array}{l}\text { În seara balului, } \\
\text { Dolores apare cu un } \\
\text { formidabil cufăr } \\
\text { rozaliu: metamorfozat, } \\
\text { eu sunt Contesa, iar } \\
\text { regele meu este Ludovic } \\
\text { al XVI-lea; am părul }\end{array}$ \\
\hline
\end{tabular}




\begin{tabular}{|c|c|}
\hline $\begin{array}{l}\text { pink box: transformed, I } \\
\text { am a Countess and my } \\
\text { king is Louis XIV; I } \\
\text { have silver hair and } \\
\text { satin slippers, a green } \\
\text { mask, am wrapped in } \\
\text { pistachio and pink: at } \\
\text { first, before the mirror, } \\
\text { this horrifies me, then } \\
\text { pleases to rapture, for I } \\
\text { am very beautiful, and } \\
\text { later, when the waltz } \\
\text { begins, Pepe, who does } \\
\text { not know, begs a dance, } \\
\text { and I, oh, sly Cinderella, } \\
\text { smile beneath my mask, } \\
\text { thinking: Ah, if I were } \\
\text { really me! Toad into } \\
\text { prince, tin into gold; fly, } \\
\text { feathered serpent, the } \\
\text { hour grows old: so ends } \\
\text { a part of my saga. (TC, } \\
\text { 73) }\end{array}$ & $\begin{array}{l}\text { argintiu și în picioare - } \\
\text { niște pantofi din satin, } \\
\text { port o mască verde și } \\
\text { sunt înfășurat în } \\
\text { mătăsuri verzi-gălbui și } \\
\text { trandafirii: la început, } \\
\text { când mă privesc în } \\
\text { oglindă, imaginea asta } \\
\text { mă înspăimântă, dar } \\
\text { apoi îmi place la } \\
\text { nebunie, căci sunt } \\
\text { frumoasă, iar mai } \\
\text { târziu, când începe } \\
\text { valsul, Pepe, care nu } \\
\text { mă recunoaște, mă } \\
\text { invită la dans și eu, ah, } \\
\text { Cenușăreasă vicleană, } \\
\text { zâmbesc în spatele } \\
\text { măștii și îmi zic: Of, ce } \\
\text { n-aș da să fiu așa cu } \\
\text { adevărat! Broscoiul se } \\
\text { preschimbă în prinț, } \\
\text { tinicheaua în aur; } \\
\text { musca în șarpe cu pene, } \\
\text { iar orele îmbătrânesc: } \\
\text { astfel se încheie o parte } \\
\text { din saga mea. (GV, } \\
\text { 152-3) }\end{array}$ \\
\hline
\end{tabular}

This telltale episode could have helped the Romanian readers realize that the effeminate, narcissistic, and openly homosexual Randolph and the "queer lady" seen by Joel watching him from a top window earlier in the novel are one and the same person, but the excision of Randolph's confession about his propensity for drag, for dressing like a woman and impersonating a female character from Ivănescu's translation postpones this revelation till the very last paragraph of the novel.

Another example of tampered translation is obvious in the following brief excerpt, where the substitution of a single personal pronoun (them for him) changes the meaning of a whole paragraph and reshapes the identity of a character: 


\begin{tabular}{|c|c|c|}
\hline $\begin{array}{l}\text {...I grieved for Pepe, not } \\
\text { because I'd lost him } \\
\text { (yes, that a little), but } \\
\text { because in the end I } \\
\text { knew Dolores would } \\
\text { find him, too... (TC, 74) }\end{array}$ & $\begin{array}{l}\text {...sufeream nu pentru că } \\
i \text {-aș fi pierdut (ba da, și } \\
\text { asta puțin, ci pentru că } \\
\text { știam că până la urmă } \\
\text { Dolores avea să-1 prindă } \\
\text { și pe el... (MI, 122) }\end{array}$ & $\begin{array}{l}\text {...sufeream de dorul lui } \\
\text { Pepe, nu fiindcă } \mathbf{l} \text { l } \\
\text { pierdusem (da, un pic și } \\
\text { din cauza asta), ci pentru } \\
\text { că știam că până la urmă } \\
\text { Dolores o să-1 găsească și } \\
\text { pe el. }(G V, 149)\end{array}$ \\
\hline
\end{tabular}

With Capote, as with Gore Vidal (in The City and the Pillar), homosexuality is a latent characteristic: the characters opt for a specific sexual orientation only after a quest, a journey leading to self-discovery. It originates from acquired experience, from a series of events that ultimately steer a character to revelation and ultimate decision. Such is the case of Joel, who, as John Berendts points out, is repeatedly described as "too pretty, too delicate and fair-skinned", with an "uncommonly soft" voice, a "sissy britches" (2). Idabel, the tomboy, overtly asks the effeminate and timid Joel to treat her as if she were a boy; in one of the most memorable graphic scenes of the novel, the two naked teenagers take a bath in the river and wash each other's back; the naked Idabel extemporaneously starts a wrestling bout with the naked Joel, but the outcome of this happening is not the arousal of natural sexual instincts - on the contrary, it ends "as if nothing had happened. And, indefinably, it was as if nothing had: neither would ever be able to explain why they had fought" (Other Voices 67). Another event that leads Joel to self-discovery is the voyeuristic scene in which he and Idabel witness the lovemaking of a young couple of Afro-Americans in the open, under the starry sky of summer. Joel is deeply impressed and seems to be tempted to experience a similar man-woman (or, rather, boy-girl) relationship with Idabel, but the latter simply inhibits his desire: "He wanted to walk with Idabel's hand in hand, but she had them doubled like knots, and when he spoke to her she looked at him mean and angry and scared" (89). This is the first hint about Idabel's latent lesbianism. The suggestion is reinforced in the episode narrating the runaway children's encounter with Miss Wisteria, the midget, at the "travelin-show": Joel is simply astounded by Idabel's silly behaviour and Joel's astonishment seems to have been shared by the translator / censor of the earlier Romanian version as well:

\begin{tabular}{|c|c|c|}
\hline $\begin{array}{l}\text { ck and } \\
\text { wpie- } \\
\text { er thing } \\
\text { el, }\end{array}$ & $\begin{array}{l}\text { la fund } \\
\text { se rujul } \\
\text { rul } \\
\text { e } \\
\text { iudat: } \\
\text { iudat } \\
\text { o clipă }\end{array}$ & $\begin{array}{l}\text { Cola, } \\
\text { și refăcu } \\
\text { ca de } \\
\text { asta se } \\
\text { dat: }\end{array}$ \\
\hline
\end{tabular}




\begin{tabular}{|c|c|c|}
\hline $\begin{array}{l}\text { clownish line across her } \\
\text { mouth, and Miss } \\
\text { Wisteria, clapping her } \\
\text { little hands, shrieked } \\
\text { with a kind of sassy } \\
\text { pleasure. Idabel met this } \\
\text { merriment with a dumb } \\
\text { adoring smile. Joel could } \\
\text { not understand what had } \\
\text { taken her. Unless it was } \\
\text { that the midget had cast } \\
\text { a spell. But as she } \\
\text { continued to fawn over } \\
\text { tiny yellow-haired Miss } \\
\text { Wisteria, it came to him } \\
\text { that Idabel was in love. } \\
\text { (TC, 91) }\end{array}$ & $\begin{array}{l}\text { batonul de ruj, își pictă o } \\
\text { linie stângace, ca de } \\
\text { paiață, pe gură, și } \\
\text { domnișoara Wisteria, } \\
\text { bătând din palmele } \\
\text { micuțe, scoase niște } \\
\text { țipete de încântare } \\
\text { prostească. Idabel primi } \\
\text { veselia aceasta cu un } \\
\text { surâs de adorație stupid. } \\
\text { Joel nu înțelegea deloc } \\
\text { ce-o apucase. Decât dacă } \\
\text { pitica nu-i făcuse cumva } \\
\text { vreo vrajă. Și pe când ea } \\
\text { continua s-o lingușească } \\
\text { în fel și chip pe micuța } \\
\text { domnișoară Wisteria cu } \\
\text { părul ei bălai, îi trecu } \\
\text { prin minte că da, Idabel } \\
\text { era vrăjită. (MI, 154) }\end{array}$ & $\begin{array}{l}\text { împrumut rujul, își pictă } \\
\text { o linie penibilă, ca de } \\
\text { clovn, pe gură și } \\
\text { domnișoara Wisteria, } \\
\text { aplaudând cu mânuțele ei } \\
\text { pitice, scoase un țipăt de } \\
\text { încântare cam sfruntată. } \\
\text { Idabel răspunse acestei } \\
\text { manifestări de voioșie cu } \\
\text { un zâmbet de adorație } \\
\text { nătângă. Joel nu pricepea } \\
\text { ce naiba a apucat-o. Doar } \\
\text { dacă nu cumva i-o fi } \\
\text { făcut pitica farmece. } \\
\text { Totuși, în timp ce Idabel } \\
\text { continua să se gudure pe } \\
\text { lângă micuța domnişoară } \\
\text { Wisteria, cu părul ei } \\
\text { bălai, îi trecu prin minte } \\
\text { că s-o fi îndrăgostit de } \\
\text { ea(GV, 195) }\end{array}$ \\
\hline
\end{tabular}

While Idabel seems to fall in love with the midget, Miss Wisteria experiences a perpetual drama: her otherness prevents her from finding a lover, from living a normal life. The surrogate of a normal relationship is her wooing of young boys who, anyway, are to grow up and become much, much taller than she is. The ferris-wheel scene perfectly illustrates her drama and it obviously needed to be partly excised and adapted in the 1978 edition:

\begin{tabular}{|c|c|c|}
\hline $\begin{array}{l}\text { She placed her hand on } \\
\text { his thigh, and then, as } \\
\text { though she had no } \\
\text { control over them } \\
\text { whatsoever, her fingers } \\
\text { crept up inside his legs: } \\
\text { she stared at the hand } \\
\text { with shocked intensity } \\
\text { but seemed unable to } \\
\text { remove it, and Joel, } \\
\text { disturbed but knowing } \\
\text { now he wanted never to } \\
\text { hurt anyone, not Miss }\end{array}$ & $\begin{array}{l}\text { Își lăsă mâna pe } \\
\text { genunchiul lui, și pe } \\
\text { urmă, ca și când nu și-ar } \\
\text { mai fi putut-o stăpâni, } \\
\text { degetele i se strânseră } \\
\text { [omitted words]; își } \\
\text { privea mâna cu un fel de } \\
\text { intensitate uimită, dar nu } \\
\text { părea în stare să și-o ia } \\
\text { de acolo. Tulburat, dar } \\
\text { știind acum că nu vroia } \\
\text { să jignească pe nimeni, } \\
\text { nici pe domnișoara }\end{array}$ & $\begin{array}{l}\text { Își lăsă mâna pe coapsa } \\
\text { lui și apoi, ca și cum nu } \\
\text { și le-ar mai fi putut ține } \\
\text { deloc în frâu, degetele ei } \\
\text { se strecurară între } \\
\text { picioarele lui: se holbă } \\
\text { la propria mână cu o } \\
\text { intensitate contrariată, } \\
\text { dar părea că nu-i în stare } \\
\text { să și-o ia de acolo, iar } \\
\text { Joel, tulburat, însă de- } \\
\text { acum conștient că nu } \\
\text { mai vrea să facă pe }\end{array}$ \\
\hline
\end{tabular}




\begin{tabular}{|c|c|c|}
\hline $\begin{array}{l}\text { Wisteria, nor Idabel, nor } \\
\text { the little girl with the } \\
\text { corncob doll, wished so } \\
\text { much he could say: it } \\
\text { doesn't matter, I love } \\
\text { you, I love your hand. } \\
\text { (TC, 92) }\end{array}$ & $\begin{array}{l}\text { Wisteria, nici pe Idabel, } \\
\text { nici pe fetița cu păpușa } \\
\text { [omitted words], Joel ar } \\
\text { fi vrut atât de mult să-i } \\
\text { poată spune: n-are a } \\
\text { face, te iubesc [omitted } \\
\text { words]. (MI, 156) }\end{array}$ & $\begin{array}{l}\text { nimeni să sufere } \\
\text { vreodată, nici pe } \\
\text { domnișoara Wisteria, } \\
\text { nici pe Idabel, nici pe } \\
\text { fetița cu păpușa din } \\
\text { știulete de porumb, tare } \\
\text { și-ar fi dorit să-i poată } \\
\text { spune: nu contează, te } \\
\text { iubesc, îți iubesc mâna. } \\
(\mathrm{GV}, 149)\end{array}$ \\
\hline
\end{tabular}

Ivănescu's version omits words in two essential moments and thus it desexualizes Miss Wisteria's action (her fingers creeping up inside his leg) as well as Joel's response to being abused by an older person (I love your hand, the hand used to arouse him). The new Romanian version has the following footnote appended to up inside his leg: "Ambiguous passage in the original, censored in the Romanian edition published during the Communist regime, which can be also translated as in cracul pantalonului." The other omission in this passage stems from the translator's inability to translate corncob into Romanian - and, as we will see in the next section of this paper, one of Ivănescu's weaknesses as a translator was the frequent mistranslation of animal and vegetable terms.

Later on, Joel, while suffering from pneumonia, has a nightmare in which he imagines himself lying dead in a coffin, with his face powdered and rouged.

\begin{tabular}{|l|l|l|}
\hline ...inside the chest lay & ...în ladă zăcea Joel & ...în sicriu zăcea însuși \\
Joel himself, all dressed & însuși, îmbrăcat tot în & Joel, înveșmântat în alb \\
in white, his face & alb, cu fața pudrată & din cap până-n picioare, \\
powdered and rouged... & $\begin{array}{l}\text { [omitted word] ... (MI, } \\
\text { 162) }\end{array}$ & $\begin{array}{l}\text { pudrat și rujat... (GV, } \\
\text { (TC, 95) }\end{array}$ \\
\hline
\end{tabular}

Although in the United States it is a common practice for morticians to powder and rouge the face of the dead, the translator / censor read this detail as an offence to common sense and as an allusion to transvestism (as in Randolph's earlier metamorphosis into a Countess). Ivănescu not only censors an innocuous detail, but also perpetuates his earlier mistake of translating chest as "ladă" [box, case] throughout the novel. Both Jesus Fever and Joel lie, according to Ivănescu, in boxes, not in coffins, although, according to The Merriam Webster's Third International Dictionary, chest means "2now dialect - COFFIN". 


\section{Mircea Ivănescu as Traduttore Tradittore}

Once considered one of the best Romanian translators from English (albeit not a translator of drama in verse or sonnets, or rhymed verse, like Leon Levițchi, Dan Duțescu and Petre Solomon), Mircea Ivănescu has been lately the subject of increasing scrutiny questioning his skills as a literary translator. The debunking of his stature began back in 1996, when the editor of the then forthcoming second edition of Joyce's Ulysses, Mihaela Dumitrescu, supervising Univers and Fundația Culturală Română's joint publishing effort, expressed serious doubts about the quality of Ivănescu's translation and demanded that it should undergo a thorough revision. Even so, the quality of his translation is considered to be unacceptable according to present-day standards, and that is why two publishing houses have almost simultaneously commissioned two talented translators, Mihnea Gafița (whose list of translated authors includes George Orwell, E. L. Doctorow and David Lodge) and Rareş Moldovan (who has likewise translated important authors such as Harold Bloom and Thomas Pynchon) to produce new versions of Ulysses.

Ivănescu the poet was able to produce impressive translations in terms of fluency and expressiveness. He often "embellished" the original texts with stylistic inventions of his own, turning stylistically arid passages into subtle, poetic laces of words that conveyed a mystifying, semantically blurred message; hence, the totally misconstrued image of Faulkner's prose for a whole generation of Romanian readers. It was in my late twenties that I came to realize that Faulkner was much more readable, enjoyable and intelligible in English than in Ivănescu's would-be poetic gibberish. This value judgment may sound too harsh but it is based on sheer facts.

Ivănescu's main flaws are lack of faithfulness to the original (he often invents a parallel story, abounding in dozens and hundreds of instances of mistranslation at the denotative level of the text) and excessive redundancy.

Here are just a few examples of such redundancies:

\begin{tabular}{|c|c|c|}
\hline $\begin{array}{l}\text { "Everything", he said } \\
\text { gently, "everything is } \\
\text { going to be all right." } \\
(\mathrm{TC}, 75)\end{array}$ & $\begin{array}{l}\text { Totul, spuse el încet, } \\
\text { totul are să se termine } \\
\text { până la urmă cu bine. } \\
\text { (MI, 124) }\end{array}$ & $\begin{array}{l}\text { Totul, spuse el încetișor, } \\
\text { totul va fibine. (GV, } \\
\text { 157) }\end{array}$ \\
\hline $\begin{array}{l}\text {... and all that happened } \\
\text { happened quickly (TC, } \\
\text { 59) }\end{array}$ & $\begin{array}{l}\text {...și tot ceea ce se } \\
\text { întâmplă seîntâmplă } \\
\text { foarte repede (MI, 96) }\end{array}$ & $\begin{array}{l}\text {...și totul se întâmplă } \\
\text { extrem de rapid (GV, } \\
121)\end{array}$ \\
\hline $\begin{array}{l}\text {... and dressing as you do } \\
\text { in no way befitting a } \\
\text { young lady... (TC, } 90)\end{array}$ & $\begin{array}{l}\text {...îmbrăcată cum nu se } \\
\text { cuvine săfie îmbrăcată o } \\
\text { domnișoară... (MI, 151) }\end{array}$ & $\begin{array}{l}\text {... te îmbraci într-un fel } \\
\text { cu totul nepotrivit } \\
\text { pentru o domnișoară } \\
(\mathrm{GV}, 192)\end{array}$ \\
\hline
\end{tabular}




\begin{tabular}{|l|l|l|}
\hline $\begin{array}{l}\text { When they reached the } \\
\text { pecan tree, tallest of the } \\
\text { two... [tallest here refers } \\
\text { to Florabel, not to the } \\
\text { tree!] (TC, 48) }\end{array}$ & $\begin{array}{l}\text { Când ajunseră iarăși la } \\
\text { pomii de care era legat } \\
\text { hamacul, la cel mai } \\
\text { innalt dintre ei... (MI, 90) } \\
\text { [flawed reference to the } \\
\text { taller tree] }\end{array}$ & $\begin{array}{l}\text { Când ajunseră } \text { la nucul } \\
\text { pecan, ea fiind cea mai }\end{array}$ \\
\end{tabular}

The latter example substantiates not only Ivănescu's penchant for long, redundant paraphrases, but also his inability to cope with the translation of vegetable terms like the pecannut. During the re-translation of Shakespeare's plays for the New Romanian Shakespeare Series launched in 2010, several fellow-translators (Violeta Popa, Horia Gârbea etc.) have remarked upon the frequent instances of mistranslation of terms defining fauna and flora in the earlier Romanian versions. And, indeed, it was quite a difficult task to translate such terms in an age lacking comprehensive explanatory dictionaries as well as specialized ones, to say nothing of the internet, Wikipedia and other useful instruments that one can access nowadays. In the days of the Communist regime, the Romanian translators could only rely on Lumea animalelor după Brehm (1964) and Milea Preda's Dicționar dendrofloricol (1989) - the latter, a very reliable reference work, was issued just a few months before the fall of Communism. However, it was not only the lack of adequate instruments that generated the huge mistakes one can stumble upon anywhere in Ivănescu's translations. It is hard to believe that he could not distinguish between a whale and a shark or a raven and a cuckoo. He was either utterly careless, neglectful, or utterly intrusive, disagreeing with the original and proposing a yarn of his own. Here are a few random examples of mistranslation of words from several semantic fields. Under the heading Mircea Ivănescu I will also provide the backtranslation of his Romanian equivalents.

\section{Vegetation}

\begin{tabular}{|c|c|c|}
\hline TRUMAN CAPOTE & MIRCEA IVĂNESCU & $\begin{array}{l}\text { GEORGE } \\
\text { VOLCEANOV }\end{array}$ \\
\hline crepe myrtle (13) & mirt $(16) \rightarrow$ myrtle & liliac indian (24) \\
\hline dogwood $(16,21,22)$ & $\begin{array}{l}\text { lemn câinesc }(22,31,34) \\
\rightarrow \text { doggy }(!) \text { wood }\end{array}$ & corn $(31,41,44)$ \\
\hline dry cornhusks $(18,22)$ & $\begin{array}{l}\text { coceni uscați de porumb } \\
(27,34) \rightarrow \text { dry corn } \\
\text { stems }\end{array}$ & pănuşi uscate $(37,45)$ \\
\hline $\begin{array}{l}\text { elephant-ear plant (27, } \\
83)\end{array}$ & $\begin{array}{l}\text { plante } \mathrm{cu} \text { frunze } \text { cât } \\
\text { urechea elefantului }(41, \\
138) \rightarrow \text { plants with }\end{array}$ & $\begin{array}{l}\text { urechea-elefantului (53, } \\
175)\end{array}$ \\
\hline
\end{tabular}




\begin{tabular}{|l|l|l|}
\hline & $\begin{array}{l}\text { leaves as huge as an } \\
\text { elephant's ear }\end{array}$ & \\
\hline $\begin{array}{l}\text { a clump of goldenrod } \\
(71)\end{array}$ & $\begin{array}{l}\text { o tufă de tufe aurii (!) } \\
(57) \rightarrow \text { a golden-bush } \\
\text { bush }\end{array}$ & un âlc de splinuțe (71) \\
\hline chinaberry (37) & $\begin{array}{l}\text { duzi } \rightarrow \text { mulberry-trees } \\
(59)\end{array}$ & cedri albi (73) \\
\hline elderberry (38) & $\begin{array}{l}\text { dud } \rightarrow \text { mulberry-tree } \\
(61)\end{array}$ & soc (75) \\
\hline rattan rocker (76) & $\begin{array}{l}\text { balansoar de răchită } \rightarrow \\
\text { wickerrocker (125) }\end{array}$ & $\begin{array}{l}\text { balansoar din } \\
\text { impletită (159) }\end{array}$ \\
\hline sweetgums (84) & $\begin{array}{l}\text { arbori de cauciuc (140) } \\
\rightarrow \text { gum-trees }\end{array}$ & $\begin{array}{l}\text { arbori de chihlimbar } \\
(178)\end{array}$ \\
\hline chews of sweetgum (85) & $\begin{array}{l}\text { scoarță de cauciuc dulce } \\
(141) \rightarrow \text { sweet gum-tree } \\
\text { bark }\end{array}$ & $\begin{array}{l}\text { rășină de arbore de } \\
\text { chihlimbar (179) }\end{array}$ \\
\hline corn (85) & grâu (142) $\rightarrow$ wheat & porumb (181) \\
\hline toadstools (88) & \multicolumn{1}{|c|}{ ciuperci otrăvite (189) } \\
\hline
\end{tabular}

Animal world

\begin{tabular}{|l|l|l|}
\hline TRUMAN CAPOTE & MIRCEA IVĂNESCU & $\begin{array}{l}\text { GEORGE } \\
\text { VOLCEANOV }\end{array}$ \\
\hline dragonflies (17) & $\begin{array}{l}\text { țâțari } \rightarrow \text { mosquitoes, } \\
\text { gnats (25) }\end{array}$ & libelule (35) \\
\hline the rainbird (37) & corbul $\rightarrow$ the raven (58) & cucul (72) \\
\hline shark (51) & balenă $\rightarrow$ whale $(81)$ & rechin (100) \\
\hline chicken hawks (56) & $\begin{array}{l}\text { pui de vultur }(90,91,92) \\
\rightarrow \text { eaglets }\end{array}$ & $\begin{array}{l}\text { ulii păsărari (111, 112, } \\
113)\end{array}$ \\
\hline chipmunks (70) & $\begin{array}{l}\text { maimuțe mititele } \rightarrow \text { tiny } \\
\text { monkeys }(115)\end{array}$ & veverițe (145) \\
\hline honeycomb (103) & stupul (178) $\rightarrow$ beehive & fagurele (228) \\
\hline cotton-mouth (86) & $\begin{array}{l}\text { gură lânoasă (144) } \rightarrow \\
\text { wooly mouth }(!)\end{array}$ & şarpe-mocasin (182) \\
\hline
\end{tabular}

According to The Merriam Webster, a rainbird is either "any of numerous birds chiefly of the family Cuculidae, whose cries are popularly believed to augur rain" or a rain crow, which, in turn is defined as "the black-billed or the yellow-billed cuckoo". It has nothing to do whatsoever with the raven, Corvus corax. Similarly, cotton-mouth is the popular name for the water-moccasin, a venomous pit viper of the southern United States. 
Everyday items

\begin{tabular}{|c|c|c|}
\hline TRUMAN CAPOTE & MIRCEA IVĂNESCU & $\begin{array}{l}\text { GEORGE } \\
\text { VOLCEANOV }\end{array}$ \\
\hline $\begin{array}{l}\text { wore a puffy, stained } \\
\text { chef's cap (16) }\end{array}$ & $\begin{array}{l}\text { purta o şapcă umflată, } \\
\text { pătată, de șef de gară } \\
(24) \rightarrow \text { wore a puffy, } \\
\text { stained station master's } \\
\text { cap }\end{array}$ & $\begin{array}{l}\text { avea pe cap o bonetă } \\
\text { mare, pătată, de bucătar } \\
\text { (32) }\end{array}$ \\
\hline $\begin{array}{l}\text { candy-striped ribbon- } \\
\text { band (18) }\end{array}$ & $\begin{array}{l}\text { panglica mânjită de } \\
\text { urme de zahăr candel } \\
(26) \rightarrow \text { candyfloss- } \\
\text { stained ribbon-band }\end{array}$ & panglica dungată (36) \\
\hline croquer sacks (18) & $\begin{array}{l}\text { pungi de hârtie }(27) \rightarrow \\
\text { paper bags }\end{array}$ & saci de cânepă (37) \\
\hline a nickel $(14,49)$ & $\begin{array}{l}\text { un ban de nichel }(19,78) \\
\rightarrow \text { a coin (made) of } \\
\text { nickel }\end{array}$ & $\begin{array}{l}\text { o monedă de cinci cenţi } \\
(28,96)\end{array}$ \\
\hline green raindrops (67) & 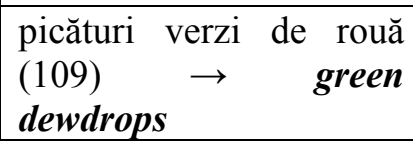 & $\begin{array}{llll}\text { stropi de ploaie } & \text { verzi } \\
(137) & & & \end{array}$ \\
\hline chest $(79,95)$ & $\begin{array}{l}\text { ladă } \rightarrow \text { box }(129,130, \\
162)\end{array}$ & $\begin{array}{l}\text { coșciug } \\
(209)\end{array}$ \\
\hline ferris wheel $(84,92)$ & $\begin{array}{l}\text { roata norocului (103, } \\
139) \rightarrow \text { wheel of } \\
\text { fortune }\end{array}$ & roata mare $(130,177)$ \\
\hline The Big Dipper (99) & $\begin{array}{ll}\text { namila } \\
\text { hoodlum }\end{array} \quad(170) \quad \rightarrow$ & Carul Mare (219) \\
\hline greased hair (99) & $\begin{array}{l}\text { părul unsuros }(170) \rightarrow \\
\text { greasy hair }\end{array}$ & $\begin{array}{llll}\text { părul dat cu briantină } \\
(218)\end{array}$ \\
\hline
\end{tabular}

The translation of raindrops as dewdrops as a means of making a literary text sound better is still acceptable, but what about turning a popular constellation, the Big Dipper, into an animate person, a human being? The aforementioned examples are evidence of the translator's poor knowledge of the source language. Ivănescu also mistakes a cook for a station master just like he mistook a train timetable (in The Great Gatsby) for a restaurant menu. 


\section{Food}

\begin{tabular}{|c|c|c|}
\hline TRUMAN CAPOTE & MIRCEA IVĂNESCU & $\begin{array}{l}\text { GEORGE } \\
\text { VOLCEANOV }\end{array}$ \\
\hline $\begin{array}{l}\text {...a cut of cornbread... } \\
\text { fried eggs and grits, } \\
\text { sopping rich with } \\
\text { sausage gravy }(30)\end{array}$ & $\begin{array}{l}\text {...coajă de pâine de } \\
\text { porumb... omletă cu } \\
\text { jumeri }(46) \rightarrow \\
\text { cornbread crust... } \\
\text { omelette with bits of } \\
\text { lard }\end{array}$ & $\begin{array}{l}\text {... bucată de lipie de } \\
\text { porumb... ouă jumări și } \\
\text { crupe mustind de sos de } \\
\text { cârnați... (58) }\end{array}$ \\
\hline $\begin{array}{l}\text { collards, yams, } \\
\text { blackeyed peas, } \\
\text { cornbread ( } 56)\end{array}$ & $\begin{array}{l}\text { cartofi, slănină, mazăre } \\
\text { neagră, pâine de cereale } \\
(91) \rightarrow \text { potatoes, bacon, } \\
\text { black peas, cereals } \\
\text { bread }\end{array}$ & $\begin{array}{l}\text { varză creață, igname, } \\
\text { fasole ochi-negri, turte de } \\
\text { mălai (111) }\end{array}$ \\
\hline buttermilk (59) & lapte $(95) \rightarrow$ milk & zer (119) \\
\hline stale crackers (88) & saleuri $(147) \rightarrow$ salés & biscuiți expirați (186) \\
\hline broth (98) & $\begin{array}{l}\text { mâncarea (169) } \rightarrow \text { the } \\
\text { food }\end{array}$ & supa concentrată (217) \\
\hline broth (99) & $\begin{array}{l}\text { terciul }(170) \rightarrow \text { mush, } \\
\text { squash }\end{array}$ & supă (218) \\
\hline
\end{tabular}

As an experienced translator, I dare claim that many of Ivănescu's blunders are simply the result of neglectfulness. One can hardly find a logical explanation for such a huge blunder as the mistranslation of fog as frog (,broască”) in a passage full of poetic force:

\begin{tabular}{|c|c|c|}
\hline $\begin{array}{l}\text {... kind of mist-white } \\
\text { palace floating foglike } \\
\text { through the woods (TC, } \\
85 \text { ) }\end{array}$ & $\begin{array}{l}\text {...un palat alb-cețos } \\
\text { plutind ca o broască prin } \\
\text { pădure (MI, 162) } \rightarrow \text { a } \\
\text { mist-white palace } \\
\text { floating froglike } \\
\text { through the forest }\end{array}$ & $\begin{array}{l}\text {...un fel de palat alb ca } \\
\text { pâcla, plutind, aidoma } \\
\text { ceții, prin codru (GV, } \\
\text { 209) }\end{array}$ \\
\hline
\end{tabular}

A frog usually jumps, as Mark Twain famously taught us in his celebrated story about a celebrated jumping frog. In Ivănescu's translation, the frog acquires surrealist skills... In the next example, the blunder stems from the translator's superfluous use of dictionaries. He read tablet as bar and decided that it referred to a chocolate bar. So far, the error is excusable. How about the Red Chief bar? At this point, the translator did not deign to solve the crux of Red Chief, which, obviously, was a cultural allusion. He simply chose to skip it in his Romanian version. This issue takes us to the realm of the ethics, or deontology, of translation. 


\begin{tabular}{|l|l|l|}
\hline $\begin{array}{l}\text { A fat horsefly dived } \\
\text { toward the Red Chief } \\
\text { tablet where Joel's } \\
\text { scrawl wobbled loosely } \\
\text { on the paper. (TC, 48) }\end{array}$ & $\begin{array}{l}\text { O muscă grasă de carne } \\
\text { plonjă spre tableta de } \\
\text { ciocolată de pe masă, } \\
\text { unde Joel isși așternea } \\
\text { mâzgăliturile pe hârtie. } \\
(\mathrm{MI}, 76)\end{array}$ & $\begin{array}{l}\text { O muscă grasă, o streche, } \\
\text { plonjă spre blocnotesul } \\
\text { cu Red Chief pe copertă } \\
\text { în care mâzgăliturile lui } \\
\text { Joel se înșirau în voie pe } \\
\text { hârtie. (GV, 93) }\end{array}$ \\
\hline
\end{tabular}

In the Romanian version published by Polirom, tablet is interpreted, in accordance with The Merriam Webster's Third International Dictionary, as "1 c a collection of sheets of paper laid together and glued at one edge and usually having a front cover." The cover represents, in this case, the hero of a short story by the great American humorist O'Henry. A footnote accompanies "Red Chief" in the 2015 Polirom edition, with a brief characterization of the protagonist and a synopsis of the eponymous story. The translation blunders we have listed are just a tip of the iceberg - this article is, after all, just another chapter in the eternal feud among the ancient and the modern, between past and present translations. It is also a necessary reassessment of canonical values: we must accept and acknowledge the fact that, as a translator, Dan Duțescu outshines by far Mircea Ivănescu; that, unlike Duțescu and Leviţchi, the great masters of "philological" translation, Ivănescu might be labelled, to paraphrase Wayne C. Booth, an "unreliable translator;" and we must also acknowledge that all these flaws cannot diminish, in the years to come, Ivănescu's stature as one of the greatest Romanian poets of the past five decades.

\section{Works Cited}

Berendt, John. "Introduction." Truman Capote. Other Voices, Other Rooms. Ebook. London: Vintage, 2007. Print.

Capote, Truman. Other Voices, Other Rooms. London: Vintage, 2007.Ebook.

Capote, Truman. Alte glasuri, alte incăperi. Romanian translation by Mircea Ivănescu. București: Univers, 1978. Print.

Capote, Truman. Alte glasuri, alte încăperi. Romanian translation and notes by George Volceanov, Iași: Polirom, 2015. Print.

Preda, Milea. Dicționar dendrofloricol, Bucureşti: Editura Ştiinţifică şi Enciclopedică, 1989. Print.

Romanowska, Agnieszka. "Mourner in the Forest of Arden: On Czesław Miłosz's Translation of As You Like It." Romanian translation by George Volceanov. Lettre Internationale (Romanian edition)88 (2014): 16-19. Print.

Slide, Anthony. Lost Gay Novels: A Reference to Fifty Works from the First Half of the Twentieth Century. Binghamton, NY: Harrington Park Press, 2003. Print. $* * *$

Lumea animalelor după Brehm.Bucureşti: Editura Ştiințifică, 1964. Print.

Merriam Webster's Third International Dictionary. Edition on CD-ROM. Version 2.5, 2000. 